\title{
Dissolved Organic Carbon Determination Using FIA and Photo-Fenton Reaction
}

\author{
Márcia M. Kondo ${ }^{1 *}$, Maria A. S. V. Arcos ${ }^{2}$ and Marco T. Grassi ${ }^{3}$ \\ ${ }^{1}$ Departamento de Física e Química, Escola Federal de Engenharia de Itajubá, 37500-176, Itajubá - MG, Brazil; \\ ${ }^{2}$ Departamento de Tecnologia Química, Universidade Federal do Maranhão, 65080-040, São Luis - MA, Brazil; \\ ${ }^{3}$ Departamento de Química, Universidade Federal do Paraná - CP 19081, 81531-990, Curitiba - PR, Brazil
}

\begin{abstract}
The FIA-photo-Fenton system is based on the flow oxidation of the organic matter. A small amount of the sample containing $\mathrm{H}_{2} \mathrm{O}_{2}$ is injected into the acidic flow solution of $\mathrm{Fe}^{2+}$, which passes through a tubular PTFE reactor irradiated with UV light. The generated $\mathrm{CO}_{2}$ is quantified by a conductometric detector and is directly proportional to the dissolved organic carbon concentration in the sample. The optimization studies were performed using EDTA solutions. The average recovery of organic carbon was $83 \%$ with a relative standard deviation of $3.7 \%$ using a $1: 5$

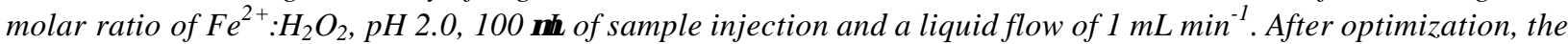
DOC concentration was quantified using 13 different organic compounds, where the average recovery was $90 \%$. The rate of the analysis was in average 50 samples hour ${ }^{-1}$.
\end{abstract}

Key words: Photo-Fenton reaction, dissolved organic carbon, FIA

\section{INTRODUCTION}

Total organic carbon (TOC) is an important parameter used as a tool to assess, for instance, the quality of a purified water. The determination and quantification of organic compounds in aqueous solution is not always an easy process which often, includes an specific analytical method. In this regard, the total organic carbon analysis can be used as an indirect method to quantify the concentration of a solution containing a single organic compound. When a more complex system is involved, TOC analysis shows the results of the sum of all organic compounds (Matthews et al., 1990).

These analyses are performed, usually, by two techniques, combustion at very high temperature, typically at $990^{\circ} \mathrm{C}$ using cobalt oxide as an oxidative catalyst, and photo-oxidation employing persulfate-ultraviolet irradiation. In both the methods, the organic carbon is converted to carbon dioxide $\left(\mathrm{CO}_{2}\right)$ which can be analyzed by infrared analyzer or flame ionization detector (APHAAAWWA-WPCF, 1995).

Recently, there has been numerous investigations (Huang et al., 1993; Venkatadri \& Peters, 1993; Lunar et al., 2000) using alternative processes to oxidize organic compounds, called advanced oxidation processes (AOP). The active species generated are the highly reactive free radicals (Huang et al., 1993; Jardim et al., 1997), mainly hydroxyl radicals $\left(\mathrm{OH}^{\circ}\right)$, which are the initiator of a chain of reactions that leads to the total

\footnotetext{
* Author for correspondence
} 
mineralization of the organic compounds to $\mathrm{CO}_{2}$, $\mathrm{H}_{2} \mathrm{O}$ and other inorganic.

The Fenton reaction is, among the AOPs, one of the most investigated. The reagent is a mixture of hydrogen peroxide and ferrous ion which produces $\mathrm{OH}^{\bullet}$ according to the equation [1] (Huston \& Pignatello, 1999; Pignatello, 1992; Engwall et al., 1999):

$$
\mathrm{Fe}^{2+}+\mathrm{H}_{2} \mathrm{O}_{2} \longrightarrow \mathrm{Fe}(\mathrm{OH})^{2+}+\mathrm{OH}^{\bullet}
$$

The literature shows that Fenton's reagent is capable of efficiently degrade several organic compounds (Huang et al., 1993; Venkatadri \& Peters, 1993; Lunar et al., 2000). In addition, Fenton reaction efficiency can be enhanced in the presence of UV irradiation (Pigantello, 1992). The iron product in equation [1] can be photoreduced regenerating $\mathrm{Fe}(\mathrm{II})$ and producing more $\mathrm{OH}^{\circ}$, as shown in equation [2]:

$$
\mathrm{Fe}(\mathrm{OH})^{2+} \stackrel{\mathrm{h} v}{\longrightarrow} \mathrm{Fe}^{2+}+\mathrm{OH}^{\bullet}
$$

The combination of Fenton reaction and UV irradiation is known as photo-assisted Fenton or photo-Fenton reaction. Bauer and Fallmann (1997) compared the wastewater treatment efficiency in a pilot scale employing AOP systems that can combine sunlight. The studied systems were $\mathrm{TiO}_{2} / \mathrm{UV}, \quad \mathrm{Fe}^{2+} / \mathrm{H}_{2} \mathrm{O}_{2} / \mathrm{UV}, \quad \mathrm{Fe}^{2+} / \mathrm{O}_{2} / \mathrm{UV}$ and $\mathrm{Fe}^{2+} / \mathrm{O}_{3} / \mathrm{UV}$. The authors observed that among the studied system, the one using photo-Fenton reaction was the most effective and also pointed out that the estimated cost is cheaper than other AOP systems.

Several researchers have investigated the photoFenton reaction as an alternative and very promising wastewater treatment process. Doong and Chang (1998) investigated the degradation of organophosphorous pesticides, such as malathion, diazon and phorate, and observed that the degradation efficiency was more effective in a system using $\mathrm{Fe}^{2+} / \mathrm{UV} / \mathrm{H}_{2} \mathrm{O}_{2}$ than in $\mathrm{H}_{2} \mathrm{O}_{2} / \mathrm{UV}$ system. The degradation of several pesticides was also investigated by Huston and Pignatello (1999). The authors showed that the pesticides were removed in less then $30 \mathrm{~min}$ and that the complete mineralization of this compounds was achieved in an average of $120 \mathrm{~min}$. Compounds such as 4 chlorobiphenyl, 4,4'-dichlorobiphenyl Kuo \& Lo, 1999), 2,4-chlorophenol, 2,4,6-trichlorophenol
(Kuo et al., 1998), and colored compounds (Liao et al., 1999; Kang et al., 1999; Wu et al., 1999) were also employed as target ones for the organic degradation study using photo-Fenton reaction. Matthews and co-workers (1990) described a new method for the determination of organic carbon using $\mathrm{TiO}_{2} / \mathrm{UV}$, another powerful AOP system. The carbon dioxide produced was monitored by conductivity detection. Sample of 1 to $40 \mathrm{~mL}$ containing 0.1 to $30 \mu \mathrm{g} \mathrm{mL}^{-1}$ of organic carbon was recirculated through a spiral borosilicate glass tube coated with $\mathrm{TiO}_{2}$. A $20 \mathrm{~W}$ black light fluorescent lamp was used as UV source. The authors reported that $99 \%$ oxidation was achieved in less than 10 minutes of irradiation. They also mentioned that the main advantages of the apparatus are the low cost and ease operation.

In the present work we investigated the possibility of using Fenton and photo-Fenton reaction as an alternative method to quantify the dissolved organic carbon concentration. As mentioned before, one of the final products of the organic compounds degradation process, in both systems, is $\mathrm{CO}_{2}$. The constructed apparatus consisted of mineralizing the organics by photo-Fenton reaction using flow injection analysis (FIA) system. The $\mathrm{CO}_{2}$ generated due to the organic compounds mineralization was quantified by monitoring the increase of the conductivity. This arrangement is similar to the one used by Fadini (1995), where the author used a FIAcondutometric system and persulfate-ultraviolet irradiation to convert organic compounds to $\mathrm{CO}_{2}$. Under these conditions, Fadini obtained an average of $88 \%$ of dissolved organic carbon recovery and the equipment was able to process 14 samples per hour.

\section{MATERIALS AND METHODS}

\section{Reagents}

Inorganic carbon standard solution (1200 $\mathrm{mg}$ of $\mathrm{C}$ $\left.L^{-1}\right), \mathrm{Na}_{2} \mathrm{CO}_{3}$ (Vetec) was dried at $270^{\circ} \mathrm{C}$ for 1 hour and $10.6 \mathrm{~g}$ was dissolved with $1 \mathrm{~L}$ to purified water, obtained from Milli-Q Academic.

Hydrogen peroxide, $30 \%$ (Alfa Caesar) was standardized by permanganate titration with a concentration of $9.7 \mathrm{~mol} \mathrm{~L}^{-1}$.

$\mathrm{Fe}^{2+}$ solution $\left(0.10 \mathrm{~mol} \mathrm{~L}^{-1}\right)$ was prepared dissolving $27.80 \mathrm{~g}$ of $\mathrm{FeSO}_{4} .7 \mathrm{H}_{2} \mathrm{O}$ (Reagen) in $1 \mathrm{~L}$ 
of an acidic solution containing $500 \mathrm{mmol} \mathrm{L}^{-1}$ of $\mathrm{H}_{2} \mathrm{SO}_{4}$ (Reagen).

Organic carbon standard solutions were prepared containing $1200 \mathrm{mg}$ of $\mathrm{C} \mathrm{L}^{-1}$. Organic compounds used in this work were EDTA (Reagen); methanol (Vetec); ethanol (Vetec); isopropanol (Nuclear); acetone (Vetec); phenol (Reagen); ascorbic acid (Reagen); hydroquinone (Vetec); pyridine (Vetec); glucose (Vetec); resorcinol (Vetec); caffeine (Nuclear), and 1,4-dioxane (Nuclear).

\section{Equipment and Analysis}

Samples containing a pre-determined amount of $\mathrm{H}_{2} \mathrm{O}_{2}$ were injected into a carrying flow of $10^{-3}$ mol L $\mathrm{L}^{-1} \mathrm{Fe}^{2+}$ acidic solution. This solution was allowed to pass through a $1.50 \mathrm{~m}$ length PTFE tube which was winded around the UV lamp $(6 \mathrm{~W}$, $\lambda=254 \mathrm{~nm}$ ). Using this tube the UV light can penetrate and irradiate the sample. During this course the organic compounds were oxidized to $\mathrm{CO}_{2}$ and $\mathrm{H}_{2} \mathrm{O}$. The $\mathrm{CO}_{2}$ passed through a PTFE membrane to a purified water flow, in a diffusion cell, increasing the water conductivity, measured with a conductometer (CPH-100). The peak intensity was recorded (Instrumentos Científicos, C.G.). Figure 1 shows a schematic representation of the FIA-photo-Fenton system.

\section{Organic carbon recovery study}

Several organic compounds were investigated. For each one of them, solutions containing 6, 12, 24, 36 and $60 \mathrm{mg} \mathrm{L}^{-1}$ of organic carbon were prepared. To quantify the percent of organic carbon recovery, the results obtained for these samples were compared to a calibration curve, using the same carbon concentrations, prepared from a stock inorganic carbon $\left(\mathrm{Na}_{2} \mathrm{CO}_{3}\right)$ standard solution.

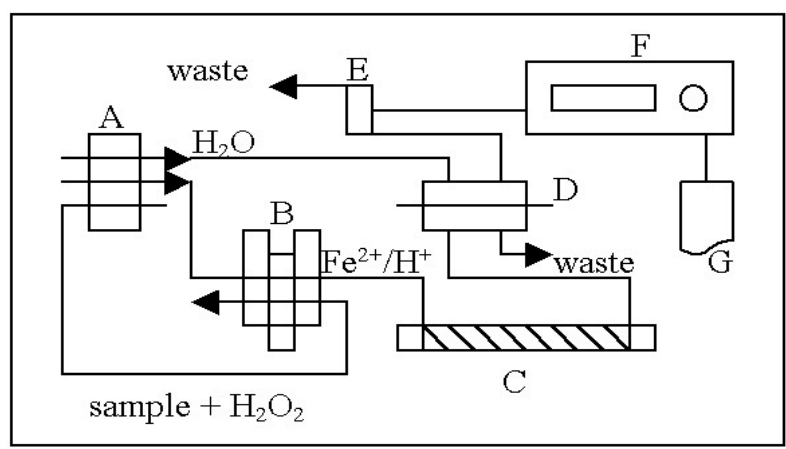

Figure 1 - Schematic representation of the FIA-photoFenton system, where (A) is the peristaltic pump, (B) the sample injector, (C) the UV lamp, (D) the diffusion cell, (E) the conductometric detector, (F) the conductometer, and $(\mathrm{G})$ the $\mathrm{X}-\mathrm{Y}$ recorder.

\section{RESULTS AND DISCUSSION}

\section{Fenton's Reagent in FIA}

A preliminary investigation was performed to determine the optimum configuration, and to know how the Fenton's reagents $\left(\mathrm{Fe}^{2+}\right.$ and $\mathrm{H}_{2} \mathrm{O}_{2}$ solutions) should be employed in FIA.

Injections of samples to an acidic $\mathrm{Fe}^{2+} / \mathrm{H}_{2} \mathrm{O}_{2}$ flow resulted in a severe instability, caused by the formation of, probably, oxygen gas bubbles. Oxygen can be formed due to the decomposition of hydrogen peroxide (Huang et al., 1993; Crittenden et al., 1999).

To avoid this problem, $\mathrm{H}_{2} \mathrm{O}_{2}$ was first introduced to the sample and then injected to the carrying flow of the $\mathrm{Fe}^{2+}$ solution. Using this condition, no bubbles were observed and the base line was kept stabilized during the analysis.

\section{Fenton x Photo-Fenton}

For this comparison study, EDTA was employed as the testing organic compound, and the FIA conditions used were $100 \mu \mathrm{L}$ of sample volume, 1 $\mathrm{mL} \mathrm{min}^{-1}$ of flow rate and $5 \mathrm{mmol} \mathrm{L}^{-1} \mathrm{H}_{2} \mathrm{O}_{2}$.

As mentioned before, Fenton's reagent is a strong oxidant that is capable to mineralize many organic compounds. The reaction time for the organic compounds mineralization depends on many parameters, such as the $\mathrm{Fe}^{2+} / \mathrm{H}_{2} \mathrm{O}_{2}$ concentration ratio, the chemical structure of testing compound, and $\mathrm{pH}$, among others. The literature shows that this time could vary from 10 to over $120 \mathrm{~min}$ (Bandara et al., 1996; Blanco et al., 1999; Kitis et al., 1999). However, due to the short period of reaction allowed in this FIA settings (less than 2 minutes), the present oxidation efficiency was low. The performance was enhanced combining Fenton's reagent and sample irradiation. Figure 2 shows the comparison of the oxidation results using Fenton and photo-Fenton reactions. Increase in the conductivity of the solution, indicated as peak height, was 9 times higher for the photoFenton system than for the Fenton system.

As already mentioned (Pignatello, 1992), the $\mathrm{OH}^{\circ}$ concentrations is higher in a photo-Fenton system compared to Fenton reaction, due to the photoreduction of $\mathrm{Fe}(\mathrm{OH})^{2+}$ to $\mathrm{Fe}^{2+}$, where more $\mathrm{OH}^{\bullet}$ is generated. Moreover, under UV radiation, the $\mathrm{H}_{2} \mathrm{O}_{2}$ undergoes direct photolysis generating two hydroxyl radicals per each peroxide molecule (Topodurti et al., 1993; Legrini et al., 1993). The $\mathrm{H}_{2} \mathrm{O}_{2}$ has a maximum absorbance in the range of 
210-240 nm, and even though one of the dominant emission wavelength of the mercury UV lamp is at $254 \mathrm{~nm}$, it is possible to generate $\mathrm{OH}^{\bullet}$ by direct photolysis of $\mathrm{H}_{2} \mathrm{O}_{2}$.

The results suggested that the Fenton reaction alone could not generate enough amounts of $\mathrm{OH}^{\circ}$ that would be capable to mineralize the organic compounds in the short time period of the FIA analysis. Under UV assisted Fenton reaction, more $\mathrm{OH}^{\circ}$ are produced and the oxidation of the organics to $\mathrm{CO}_{2}$ can be enhanced in the same period.

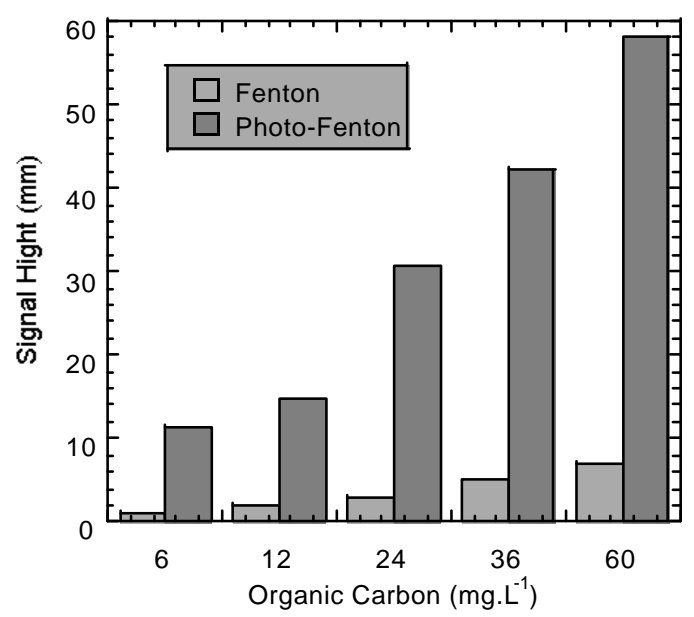

Figure 2 - Comparison of the peak intensity produced using FIA-Fenton and FIA-photo-Fenton systems, with EDTA as a testing compound, $5 \times 10^{-3}$ mol. $\mathrm{L}^{-1}$ of $\mathrm{H}_{2} \mathrm{O}_{2}$, sample volume of $100 \mu \mathrm{L}$, and $1 \mathrm{~mL} \cdot \mathrm{min}^{-1}$ of flow rate.

\section{System Optimization}

A. $\mathrm{Fe}^{2+} / \mathrm{H}_{2} \mathrm{O}_{2}$ Concentration Ratio. The literature shows that apparently there is not an unique ratio between $\mathrm{H}_{2} \mathrm{O}_{2}$ and $\mathrm{Fe}^{2+}$ concentration that could be used to oxidize organic compounds. Degradation studies using 2-chlorophenol and ionic surfactants were reported employing $\mathrm{Fe}^{2+}: \mathrm{H}_{2} \mathrm{O}_{2}$ molar ratio of 1:100 and 1:1, respectively (Huang et al., 1993; Kitis et al., 1999). Therefore, in this work, different $\mathrm{Fe}^{2+}: \mathrm{H}_{2} \mathrm{O}_{2}$ molar concentration ratios were investigated. The experiments were performed using $1.0 \mathrm{~mL} \mathrm{~min}{ }^{-1}$ flow rate and 100 $\mu \mathrm{L}$ of sampling volume.

Figure 3 shows the average percentage recovery as organic carbon in EDTA solutions. The results showed a higher organic carbon recovery at a $\mathrm{Fe}^{2+}: \mathrm{H}_{2} \mathrm{O}_{2}$ molar ratio of $1: 3 ; 1: 4$ and 1:5. At these ratios the average recovery was 70,73 and $74 \%$, respectively. Due to the slightly higher recovery obtained using 1:5 of $\mathrm{Fe}^{2+}: \mathrm{H}_{2} \mathrm{O}_{2}$ molar concentration ratio, this one was chosen to be used for further studies.

B. $p H$.

According to Huang et al. (1993), the hydrogen peroxide decomposition rate for Fenton reaction reached the maximum at a $\mathrm{pH}$ of 3.5. They attributed this phenomenon to the large catalytically active surface for $\mathrm{H}_{2} \mathrm{O}_{2}$ contact due to the progressive hydrolysis of the ferric iron. As a consequence, more free hydroxyl radicals were formed. For the photo-Fenton reaction, however, the optimum $\mathrm{pH}$ is at 2.8, where both $\mathrm{Fe}$ (III) species, present as $\mathrm{Fe}^{3+}$ and $\mathrm{Fe}(\mathrm{OH})^{2+}$, have approximately the same concentration. At lower $\mathrm{pH}$ values, the $\mathrm{Fe}(\mathrm{OH})^{2+}$ concentration decreases and at higher $\mathrm{pH}$ values, $\mathrm{Fe}(\mathrm{III})$ hydroxide precipitates (Pignatello, 1992). Nogueira and Guimarães (2000) also verified that the optimum $\mathrm{pH}$ range for photo-Fenton process was at range of 2.5-2.8, studying the degradation of dichloroacetic acid and 2,4-dichlorophenol.

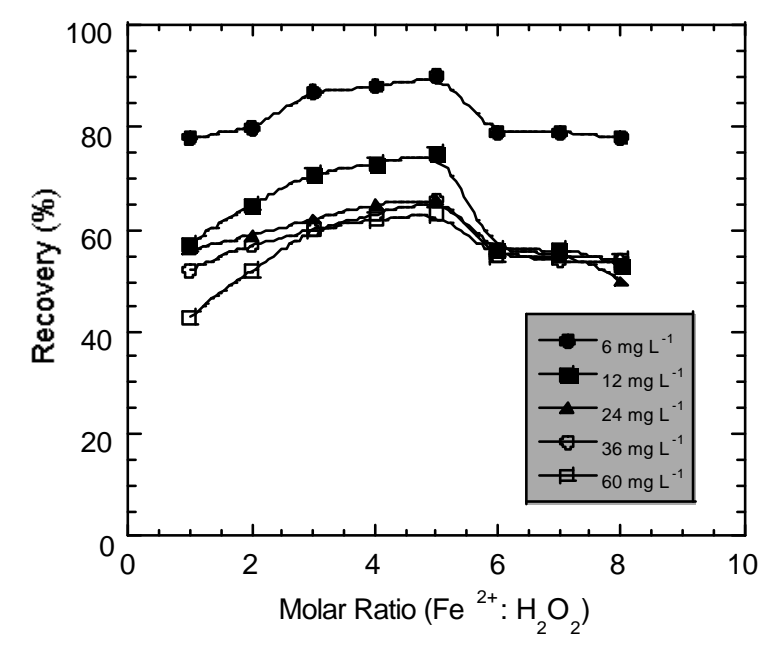

Figure 3 - Organic carbon recovery as a function of $\mathrm{Fe}^{2+}$ and $\mathrm{H}_{2} \mathrm{O}_{2}$ molar ratio, using different concentration of EDTA (mg. $\left.\mathrm{L}^{-1}\right)$ as a testing compound, $100 \mu \mathrm{L}$ of sample volume, and $1 \mathrm{~mL} \cdot \mathrm{min}^{-1}$ of flow rate.

Studies using FIA and condutometric detection (Jardim et al., 1990) to monitor the microorganism $\mathrm{CO}_{2}$ production in a liquid medium containing Escheririchia coli cultures showed better results using $10^{-2} \mathrm{~mol} \mathrm{~L}^{-1}$ of $\mathrm{H}_{2} \mathrm{SO}_{4}$. The $\mathrm{pH}$ of this 
solution was theoretically 1.7 . Due to the fact that the present apparatus was a combination of photoFenton reaction in a FIA system, different $\mathrm{pH}$ values for the $\mathrm{Fe}^{2+}$ solution were studied. The optimum organic carbon recovery results were obtained using $5 \mathrm{mmol} \mathrm{L}^{-1} \mathrm{H}_{2} \mathrm{SO}_{4}$ which resulted in $\mathrm{pH}$ value of 2.0. At higher $\mathrm{pH}$ values, the system presented an increase in instability.

\section{Sampling Volume}

The sample volume to be injected into FIA system was the other parameter optimized. Figure 4 shows the average organic carbon recovery obtained using four different sampling volumes. Results showed a higher dispersion in recovery tests when 50 or $200 \mu \mathrm{L}$ of samples were injected. The optimum results were observed using $100 \mu \mathrm{L}$ of injection volume, with an average organic carbon recovery of $81 \%$ and a $5.5 \%$ of variation coefficient among results.

\section{Flow Rate}

Several flow rates were employed. It was observed that the highest organic carbon recovery results were obtained using either 0.8 or $1.0 \mathrm{~mL} \mathrm{~min}^{-1}$. Statistically, using the T test at $95 \%$ confidence, there was no difference in the results among them. Lower values of flow rates resulted in system instability. At higher ones, the reagent diffusion into the sample cannot be totally accomplished and consequently, the oxidation of the organic could not be complete.

The following studies were performed using the flow rate of $0.8 \mathrm{~mL} \mathrm{~min}^{-1}$. The reason was that different organic compounds undergo oxidation at the different rates (Huston \& Pignatello, 1999; Maletzky \& Bauer, 1998; Krutzler \& Bauer, 1999), therefore, the reaction time could be slightly higher at $0.8 \mathrm{~mL} \mathrm{~min}^{-1}$ than at $1.0 \mathrm{~mL} \mathrm{~min}^{-}$ 1. As a consequence, the oxidation percentage should also be higher.

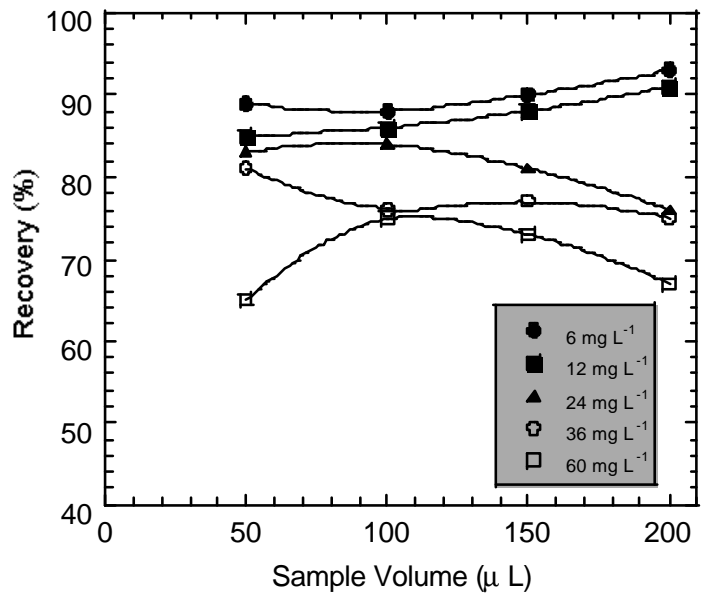

Figure 4 - Organic carbon recovery as a function of sample volume, using using different concentration of EDTA (mg. $\mathrm{L}^{-1}$ ) as a testing compound, $\mathrm{Fe}^{2+}: \mathrm{H}_{2} \mathrm{O}_{2}$ molar ratio of $1: 5, \mathrm{pH}$ value of 2.0 and $1 \mathrm{~mL} \cdot \mathrm{min}^{-1}$ of flow rate.

Organic Carbon Recovery Study. Although the experimental parameters were optimized using EDTA as a test compound, for practical purpose, they were not modified for this study. Glucose, caffeine, pyridine, methanol, ethanol, isopropanol, resorcinol, phenol, acetone, hydroquinone, ascorbic acid and 1,4-dioxane were used, each one at the same concentration of organic carbon. Table 1 shows the average organic carbon recovery obtained for all the compounds studied. For most of the compounds investigated $100 \%$ recovery could be reached. Ascorbic acid recovery was in the range of $90 \%$, EDTA and caffeine at $80 \%$ and isopropanol and acetone at $75 \%$. It is known that the degradation rate is different for each compound (Jardim et al., 1997). Therefore, modifications of some of the system parameters, could probably enhance the percentage recovery of the organics that did not reach $100 \%$.

Matthews and co-workers (1990) used $\mathrm{TiO}_{2} / \mathrm{UV}$, another powerful AOP system, to oxidize organic compounds to $\mathrm{CO}_{2}$ and consequently determine the total organic carbon concentration. The authors investigated 11 compounds and reported that $99 \%$ oxidation was achieved in less than 10 minutes. They reported that the method was suitable for samples containing 0.1 to $30 \mu \mathrm{g} \mathrm{mL}^{-1}$ of organic carbon and sample volumes of 1 to $40 \mathrm{~mL}$. 
Table 1 - Average recovery (\%) of organic carbon obtained using FIA-photo-Fenton system with several organic compounds:

\begin{tabular}{lc}
\hline \multicolumn{1}{c}{ Organic } & $\begin{array}{c}\text { Average } \\
\text { Recovery }(\%)\end{array}$ \\
\hline 1,4-Dioxane & 100 \\
Acetone & 72 \\
Ascorbic acid & 91 \\
Caffeine & 83 \\
EDTA & 80 \\
Ethanol & 100 \\
Glucose & 98 \\
Hydroquinone & 100 \\
Isopropanol & 74 \\
Methanol & 100 \\
Phenol & 100 \\
Pyridine & 100 \\
Resorcinol & 100 \\
\hline
\end{tabular}

Determination of DOC in real samples. Aqueous samples of four different sources were used to verify the efficiency of the FIA-photo-Fenton system in quantifying the DOC concentration. These results were compared to the ones obtained using a commercial TOC equipment (Shimadzu, TOC 5000). The comparison is presented in table 2. In general, it could be seen that there was not a significant difference among the values obtained using either methods.

Using a similar FIA apparatus, but employing persulfate/UV as the oxidant agent, Fadini (1995) compared the dissolved organic carbon results with the ones using the same commercial TOC equipment. The values obtained from Shimadzu TOC 5000 were on average $12 \%$ higher than the FIA system using persulfate/UV.

Table 2 - Comparison of organic carbon results obtained using FIA-photo-Fenton system and a commercially available TOC equipment:

\begin{tabular}{ccc}
\hline Sample & $\begin{array}{c}\text { FIA-photo-Fenton } \\
\text { org. C }\left(\mathrm{mg} \mathrm{L}^{-1}\right)\end{array}$ & $\begin{array}{c}\text { commercial TOC } \\
\text { org. C }\left(\mathrm{mg} \mathrm{L}^{-1}\right)\end{array}$ \\
\hline 1 & 3.5 & 2.9 \\
2 & 2.7 & 2.7 \\
3 & 3.5 & 3.1 \\
4 & 4.3 & 4.3 \\
\hline
\end{tabular}

Although further studies have to be done in order to cover a wider range of dissolved organic carbon analysis, it is important to emphasize that the present system has some advantages. The rate of the analysis was on average 50 samples hour ${ }^{-1}$, using a sample volume of $100 \mu \mathrm{L}$. Moreover, using the present apparatus, there was no need for a special carrying gas neither for high temperatures to oxidize the organics, therefore, it could be used during field analysis.

\section{ACKNOWLEDGEMENTS}

This work was partially funded by CAPES and FAPEMA.

\section{RESUMO}

O sistema FIA-foto-Fenton é baseado na oxidação em fluxo da matéria orgânica. Uma pequena quantidade de amostra contendo $\mathrm{H}_{2} \mathrm{O}_{2}$ é introduzida no fluxo de uma solução ácida de $\mathrm{Fe}^{2+}$, que passa por um reator tubular de PTFE irradiado com luz UV. $\mathrm{O} \quad \mathrm{CO}_{2}$ gerado é quantificado condutometricamente e é diretamente proporcional à concentração de carbono orgânico dissolvido na amostra. Os estudos de otimização foram realizados empregando soluções de EDTA. A recuperação média de carbono orgânico foi de $83 \%$ com desvio padrão relativo de $3,7 \%$ empregando $100 \mu \mathrm{L}$ de amostra, $\mathrm{pH} 2,0$, razão molar entre $\mathrm{Fe}^{2+}$ e $\mathrm{H}_{2} \mathrm{O}_{2}$ de 1:5 e uma vazão de 1 $\mathrm{mL} \cdot \mathrm{min}^{-1}$. Após otimização as concentrações de DOC foram quantificadas em 13 diferentes compostos orgânicos, com uma recuperação média de $90 \%$. A velocidade de análise foi em média 50 amostras/h.

\section{REFERENCES}

APHA-AWWA-WPCF (1995), Standard Methods for the Examination of Water and Wastewater, American Public Health Association, Washington, DC, $19^{\text {th }} \mathrm{ed}$. ch. 5.

Bandara, J.; Morrison, C.; Kiwi, J.; Pulgarin, C. and Peringer, P. (1996), Degradation/decoloration of concentrated solution of Orange II. Kinetics and quantum yield for sunlight induced reaction via Fenton type reagents. J. Photochem. Photobiol. A Chem., 99, 57-66.

Bauer, R. and Fallmann, H. (1997), The photo-Fenton oxidation- a cheap and efficient wastewater treatment method. Res. Chem. Intermed. 23, 341-354. 
Blanco, J.; Malato, S.; Milow, B.; I. Maldonado, M.; Fallmann, H.; Krutzler, T. and Bauer, R. (1999), Techno-economical assessment of solar detoxification systems with compound parabolic collectors. J. Phys., 9, 259-264.

Crittenden, J. C.; Hu, S.; Hand, D. W. and Green, S. A. (1999), A kinetic model for $\mathrm{H}_{2} \mathrm{O}_{2} / \mathrm{UV}$ process in a completely mixed batch reactor. Wat. Res. 33, 23152328.

Doong, R. A. and Chang, W. H. (1998), Photoassisted iron compound catalytic degradation of organophosphorous pesticides with hydrogen peroxide. Chemosphere. 37, 2563-2572.

Engwall, M. A.; Pignatello, J. J. and Grasso, D. (1999), Degradation and detoxification of the wood preservatives creasote and pentachlorophenol in water by the photo-Fenton reaction. Wat. Res. 33, 11511158.

Fadini, P. S. (1995), Measuring dissolved organic carbon in natural samples by flow injection analysis. Master Thesis, Universidade Estadual de Campinas, São Paulo, Brazil.

Huang, C. P.; Dong, C. and Tang, Z. (1993), Advanced chemical oxidation: its present role and potential future in hazardous waste treatment. Waste Manag. 13, 361-377.

Huston, P. L. and Pignatello, J. J. (1999), Degradation of selected pesticide active ingredients and commerciall formulations in water by the photoassisted Fenton reaction. Wat. Res. 33, 1238-1246.

Jardim, W. F.; Moraes, S. G. and Takiyama, M. M. K. (1997), Photocatalytic degradation of aromatic chlorinated compounds using $\mathrm{TiO}_{2}$ : toxicity of intermediates. Wat. Res. 31, 1728-1732.

Jardim, W. F.; Pasquini, C.; Guimarães, J. R. and Faria, L. C. (1990), Short-term toxicity test using Escherichia coli: monitoring $\mathrm{CO}_{2}$ production by flow injection analysis. Wat. Res. 24, 351-354.

Kang, S. F.; Liao, C. H. and Hung, H. P. (1999), Peroxidation treatment of dye manufacturing wastewater in the presence of ultraviolet light and ferrous ions. J. Hazard. Mater. 65, 317-333.

Kitis, M.; Adams, C. D. and Daigger, G. T. (1999), The effects of Fenton's reagent pretreatment on the biodegradability of nonionic surfactants. Wat. Res. 33, 2561-2568.

Krutzler, T. and Bauer, R. (1999), Optimization of a photo-Fenton prototype reactor. Chemosphere, 38, 2517-2532.

Kuo, C. Y. and Lo, S. L. (1999), Oxidation of aqueous chorobiphenyls with photo-Fenton process. Chemosphere, 38, 2041-2051.
Kuo, C. Y.; Lo, S. L. and Chan, M. T. (1998), Oxidation of aqueous chlorophenols with photoFenton process. J. Environ. Sci. Health Part B-Pestic. Contam. Agric. Wastes, 33, 723-747.

Legrini, O.; Oliveros, E. and Braun, A. M. (1993), Photochemical processes for water treatment. Chem. Rev. 93, 671-698.

Liao, C. H.; Kang, S. F. and Hung, H.P. (1999), Simultaneous removal of COD and color from dye manufacturing process wastewater using photoFenton oxidation process. J. Environ. Sci. Health Part A-toxic/hazard. Subst. Environ. Eng. 34, 989-1012.

Lunar, L.; Sicilia, D.; Rubio, S.; Pérez-Bendito, D. and Nickel, U. (2000), Degradation of photographic developers by Fenton's reagent: condition optimization and kinetics for metol oxidation. Wat. Res. 34, 1791-1802.

Maletzky, P. and Bauer, R. (1998), The photo-Fenton method - degradation of nitrogen containing organic compounds. Chemosphere, 37, 899-909.

Matthews, R. W.; Abdullah, M. and Low, G. K. C. (1990), Photocatalytic oxidation for total organic carbon analysis. Analytica Chem. Acta., 233, 171-179.

Nogueira, R. F. P. and Guimarães, J. R. (2000), Photodegradation of dichloroacetic acid and 2,4dichlorophenol by ferrioxalate $/ \mathrm{H}_{2} \mathrm{O}_{2}$ system. Wat. Res., 34, 895-901.

Pignatello, J. J. (1992), Dark and photoassisted $\mathrm{Fe}^{3+}$ catalyzed degradation of chlorophenox herbicides by hydrogen peroxide. Environ. Sci. Technol. 26, 944951.

Topudurti, K. V.; Lewis, N. M. and Hirsh, S. R. (1993), The applicability of UV/oxidation technologies to treat contaminated groundwater. Environ. Progress, 12, 54-60.

Venkatadri, R. and Peters, R. W. (1993), Chemical oxidation technologies: ultraviolet light/hydrogen peroxide, Fenton's reagent, and titanium dioxideassisted photocatalysis. Hazard. Waste Hazard. Materials, 10, 107-149.

Wu, K. Q.; Xie, Y. D.; Zhao, Z. C. and Hidaka, H. (1999), Photo-Fenton degradation of a dye under visible light irradiation. J. Mol. Catal. A-Chem. 144, 77-84.

Received: September 21, 2000; Revised: April 16, 2001 Accepted: August 03, 2001. 